\title{
Evaluation of the effects of mandarin (Citrus reticulate) by-products containing citric acid on immobilization of cadmium in arable soils
}

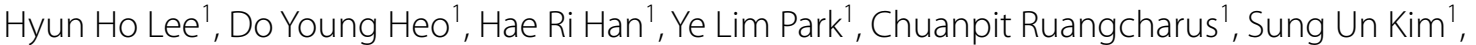 \\ Dong Cheol Seo ${ }^{2}$, Taek-Keun $\mathrm{Oh}^{3}$ and Chang Oh Hong ${ }^{1,4^{*}}$
}

\begin{abstract}
In a pilot study, we observed cadmium (Cd) immobilization with citric acid (CA) and suggested that mandarin byproducts (MB), which contain CA at ca. 1.65\%, can be used as soil amendments that reduce Cd bioavailability. In the present study, we (1) elucidated mechanisms of Cd immobilization by CA and (2) evaluated the use of MB as a soil amendment for $\mathrm{Cd}$ immobilization. In Experiment 1, CA was mixed with $\mathrm{Cd}$ contaminated soil at 0 and $3.5 \mathrm{mmol} \mathrm{kg}^{-1}$. We then added MB to Cd-spiked soil at 10,20, and $40 \mathrm{~g} \mathrm{~kg}^{-1}$. Addition of CA decreased F2 (surface adsorbed Cd fraction) contents by $2.64 \mathrm{mg} \mathrm{kg}^{-1}$ compared with the control but was associated with increases in Cd fractions F1 (bioavailable Cd fraction) and F5 (residual Cd fraction) of 1.04 and $1.49 \mathrm{mg} \mathrm{kg}^{-1}$, respectively. Addition of CA enhanced the concentration of fraction $\mathrm{F} 5$, likely reflecting $\mathrm{Cd}$ precipitation from soil solutions with increased $\mathrm{HCO}_{3}{ }^{-}$ concentrations. However, although this treatment immobilized $\mathrm{Cd}$, it also led to increasing residual and bioavailable $\mathrm{Cd}$ fractions. Unlike CA treatments, MB increased non-bioavailable $\mathrm{Cd}$ fractions without increasing the bioavailable $\mathrm{Cd}$ fraction. Moreover, at $40 \mathrm{~g} \mathrm{~kg}^{-1}, \mathrm{MB}$ decreased F1 contents by $8 \%$ compared with the control, but increased F2, $\mathrm{F} 3$, and $\mathrm{F} 5$ contents by $3.6 \%, 0.7 \%$, and $4.5 \%$, respectively. $\mathrm{Cd}$ may be immobilized by $\mathrm{MB}$ through $\mathrm{H}_{x} \mathrm{CO}_{3}{ }^{-}$mediated precipitation as $\mathrm{CdCO}_{3}$ following decomposition of $\mathrm{CA}$ and concomitant increases in the negative charge of soil due to the organic matter in MB. MB also improved the chemical properties of soils, with increased nutrient concentrations and cation exchange capacities.
\end{abstract}

Keywords: Cadmium, Carbonate, Citric acid, Immobilization, Mandarin byproduct

\section{Introduction}

Recently, the production of cadmium (Cd) containing compounds has dramatically increased due to rapid industrialization [1]. The annual world total production of Cd in 2018 was 26,000 tons [2]. Most of the world's primary $\mathrm{Cd}$ metal was produced in Asia, and the leading global producers were China, the Republic of Korea, and Japan. The wide use of $\mathrm{Cd}$ containing materials in industry results in irreversible environmental exposures to $\mathrm{Cd}$, which finally ends up in the soil [3]. Due to its high toxicity in the food chain, the presence of $\mathrm{Cd}$ in arable soils

\footnotetext{
${ }^{*}$ Correspondence: soilchem@pusan.ac.kr

1 Department of Life Science and Environmental Biochemistry, Pusan

National University, Miryang 50463, Republic of Korea

Full list of author information is available at the end of the article
}

could be hazardous to humans, even at low levels $[4,5]$. Cadmium poisoning causes itai-itai disease, and chronic exposure to $\mathrm{Cd}$ can result in nephrotoxicity in humans, mainly reflecting the development of abnormalities in tubular re-absorption [6, 7]. According to previous studies of heavy metals in agricultural soils, Cd was ranked among the most harmful heavy metals of major heavy metal contaminants globally [8].

Phytoremediation is an optimal technology for restoring $\mathrm{Cd}$ contaminated arable soils, and is economically and environmentally appropriate. Over several decades, many studies demonstrate phytoremediation of Cd contaminated arable soils [9-17]. In some of these, chelating agents that increase the extractability of $\mathrm{Cd}$ were used to boost uptake of this metal by hyperaccumulators $[9,11,12,15]$. Chelating agents such as citric 
acid (CA), diethylenetriaminepentaacetic acid (DTPA), ethylenediaminetetraacectic acid (EDTA), ethylenebis (oxyethylenenitrilo)-tetraacetic acid (EGTA), maleic acid, and trans-1,2-diaminocyclohexane- $N, N, N^{\prime}, N^{\prime}$-tetraacetic acid (CDTA), form metal-ligand complexes with $\mathrm{Cd}^{2+}$ that are more readily taken up by plant roots than the free ion $\mathrm{Cd}^{2+}[18,19]$. Therefore, the application of chelating agents to conventional phytoremediation techniques in $\mathrm{Cd}$ contaminated soil has received keen interest. Although these techniques are highly effective, we observed Cd immobilization with CA in our recent pilot study [20]. We reported that concentrations of non-bioavailable $\mathrm{Cd}$ fractions increased following addition of $\mathrm{CA}$, but we did not precisely demonstrate the related mechanism of $\mathrm{Cd}$ immobilization with $\mathrm{CA}$.

Mandarin orchards cover 20,140 ha in the Jeju island region of South Korea, where approximately $576,722 \mathrm{Mg}$ of mandarins were produced in 2017 [21]. About 51,000 ton of mandarin byproduct (MB) is dumped annually in Jeju [22], and this byproduct generates potent odors, leads to destruction of the natural landscape, and causes various environmental problems. Therefore, utilization of $\mathrm{MB}$ has become an imminent issue in Jeju. Yet, because biosynthetic sources offer a plentiful supply of organic acids, recycling of MB is limited. Mandarin is a representative citrus fruit that contains very high quantities of organic acid. Its scientific name Citrus reticulate implies that $\mathrm{CA}$ is the major organic acid component of mandarins. Although many studies show uses of $\mathrm{MB}$ in various fields, use as a soil amendment for remediating $\mathrm{Cd}$ in arable soil has not been reported previously. Because $\mathrm{MB}$ contains CA at ca. 1.65\%, we investigated its effects as a soil amendment to reduce $\mathrm{Cd}$ bioavailability in soils. Specifically, we (1) elucidated the mechanism of Cd immobilization by $\mathrm{CA}$ and (2) evaluated the feasibility of $\mathrm{MB}$ as a soil amendment for $\mathrm{Cd}$ immobilization.

\section{Materials and methods}

\section{Soil characteristics and $\mathrm{Cd}$ spiking}

Upland soil was collected from the top $10 \mathrm{~cm}$ at an experimental field of Pusan National University $\left(128^{\circ} 43^{\prime} \mathrm{N}\right.$ and $35^{\circ} 30^{\prime}$ E), Republic of Korea. Soil samples were air-dried and ground through a 2-mm sieve. Selected physical and chemical properties of the soil samples are summarized in Table 1. Soils were spiked with $\mathrm{CdCl}_{2} \cdot 2.5 \mathrm{H}_{2} \mathrm{O}$ to give a total Cd concentration of $20 \mathrm{mg} \mathrm{Cd} \mathrm{kg}{ }^{-1}$ [23]. Subsequently, $20 \mathrm{~kg}$ arable soil samples were added to $15 \mathrm{~L}$ of distilled water containing $0.813 \mathrm{~g}$ of $\mathrm{CdCl}_{2} \cdot 2.5 \mathrm{H}_{2} \mathrm{O}$ to achieve a Cd concentration of $20 \mathrm{mg} \mathrm{kg}^{-1}$. The resulting mixtures were subjected to an aging period, because solutions of $\mathrm{CdCl}_{2} \cdot 2.5 \mathrm{H}_{2} \mathrm{O}$ contain mostly soluble forms of Cd. After Cd-spiked soils were completely dried, $15 \mathrm{~L}$ aliquots of distilled water were spread and mixed thoroughly with soils using a plastic spatula. Soils were then

Table 1 Selected properties of soil and mandarin by-product

\begin{tabular}{|c|c|c|}
\hline Studied material & Items & Concentration \\
\hline \multirow[t]{16}{*}{ Soil } & $\mathrm{pH}\left(1: 5\right.$ with $\left.\mathrm{H}_{2} \mathrm{O}\right)$ & 6.71 \\
\hline & Total nitrogen $\left(\mathrm{g} \mathrm{kg}^{-1}\right)$ & 1.05 \\
\hline & Organic matter $\left(\mathrm{g} \mathrm{kg}^{-1}\right)$ & 17.6 \\
\hline & Available phosphorus $\left(\mathrm{mg} \mathrm{kg}^{-1}\right)$ & 142 \\
\hline & Cation exchange capacity $\left(\mathrm{cmol}_{\mathrm{c}} \mathrm{kg}^{-1}\right)$ & 6.85 \\
\hline & Exchangeable cation $\left(\mathrm{cmol}_{\mathrm{c}} \mathrm{kg}^{-1}\right)$ & \\
\hline & $\mathrm{Ca}$ & 4.76 \\
\hline & K & 0.42 \\
\hline & $\mathrm{Mg}$ & 0.93 \\
\hline & $\mathrm{Na}$ & 0.38 \\
\hline & Total concentration of cadmium ( $\mathrm{mg} \mathrm{kg}^{-1}$ ) & trace \\
\hline & Bulk density $\left(\mathrm{g} \mathrm{m}^{-3}\right)$ & 1.41 \\
\hline & Soil texture & Sandy loam \\
\hline & Clay (\%) & 14.9 \\
\hline & Silt (\%) & 25.7 \\
\hline & Sand (\%) & 59.4 \\
\hline \multirow{5}{*}{$\begin{array}{l}\text { Mandarin by-product } \\
\text { (Citrus reticulate) }\end{array}$} & $\mathrm{pH}\left(1: 5\right.$ with $\left.\mathrm{H}_{2} \mathrm{O}\right)$ & 4.02 \\
\hline & Total nitrogen $\left(\mathrm{g} \mathrm{kg}^{-1}\right)$ & 22.9 \\
\hline & Organic matter $\left(\mathrm{g} \mathrm{kg}^{-1}\right)$ & 85.1 \\
\hline & Total concentration of cadmium ( $\mathrm{mg} \mathrm{kg}^{-1}$ ) & trace \\
\hline & Citric acid $\left(\%, w t w^{-1}\right)$ & 1.65 \\
\hline
\end{tabular}


air-dried and the aging process was repeated three times more over 70 days.

\section{MB properties}

$\mathrm{MB}$ was provided by the mandarin processing plant at Seogwipo-si $\left(126^{\circ} 66^{\prime} \mathrm{N}\right.$ and $\left.33^{\circ} 32^{\prime} \mathrm{E}\right)$, Republic of Korea. $\mathrm{MB}$ was air-dried and crushed using a blender and was then filtered through a $0.84-\mathrm{mm}$ sieve for analyzes of chemical properties (Table 1).

\section{Incubation tests}

\section{Experiment 1: effects of CA on Cd immobilization}

CA was added to $200 \mathrm{~g}$ samples of pretreated soils to concentrations of 0 and $3.5 \mathrm{mmol} \mathrm{kg}{ }^{-1}$ in $160 \mathrm{~mL}$ plastic beakers. Soil mixtures were then incubated in the dark at $25^{\circ} \mathrm{C}$ for 6 weeks, wetted to $70 \%$ of corresponding pore volumes, and weighed every 2 days to maintain water contents. Soil mixtures were then randomly placed in an incubator and experiments were conducted with four replications.

\section{Experiment 2: feasibility of $M B$ as a soil amendment that immobilizes $C d$}

$\mathrm{MB}$ was added to $200 \mathrm{~g}$ samples of pretreated soil to concentrations of $0,10,20$, and $40 \mathrm{~g} \mathrm{~kg}^{-1}$ in $160 \mathrm{~mL}$ plastic beakers. Experiment 2 was conducted under the same conditions as described above for Experiment 1.

After the incubation periods in Experiments 1 and 2, soils were dried and sieved through $<2 \mathrm{~mm}$ filters for further extraction and chemical analysis.

\section{Chemical analysis}

Soil $\mathrm{pH}\left(1: 5, \mathrm{H}_{2} \mathrm{O}\right)$ was measured using a $\mathrm{pH}$ meter (Starter 3000, Ohaus, USA). Negative charges of soils were analyzed by measuring $\mathrm{K}^{+}$retention as described by Macrano-Martinez and Mcbride [24] with some modifications. Dissolved organic carbon (DOC) was quantified using a total organic carbon (TOC) analyzer (Model TOC-VCPN; Shimadzu, Japan).

After 6-weeks incubation, soils were air-dried and digested with aqua regia $\left(3: 1, \mathrm{HCl}: \mathrm{HNO}_{3}\right)$ for analysis of total $\mathrm{Cd}$ concentrations. $\mathrm{Cd}$ was then sequentially extracted from soils using a modified sequential $\mathrm{Cd}$ extraction method $[25,26]$. After $\mathrm{Cd}$ fractionation, suspensions were centrifuged at $605 \times g$ for $15 \mathrm{~min}$ to separate thoroughly extractants from soils. The remaining supernatants were then filtered through $0.45 \mu \mathrm{m}$ cellulose acetate membrane filters and $\mathrm{Cd}$ contents were quantified using atomic absorption spectroscopy (AAS; Perkin Elemer Model 3300, Shelton, Connecticut, USA).

The present five modified $\mathrm{Cd}$ fractions differ in bioavailability, binding strength, and chemical form [27, 28]. In particular, $\mathrm{Cd}$ fraction 1 (F1) is a bioavailable fraction that contains water soluble, exchangeable, and weak-acidic extractable forms of $\mathrm{Cd}$. Cd fraction 2 (F2) was the surface adsorption fraction and contained the immobilized $\mathrm{Cd}$ form from soils. F2 is not readily taken up by plants because it is tightly bound to surfaces of soil colloids by specific adsorption or weak carbonated bonds. Cadmium fraction 3 (F3) is strongly complexed by organic matter. Cadmium fraction 4 (F4) is the reducible fraction that is associated with iron (Fe) and manganese (Mn) oxides. Cadmium fraction 5 (F5) is the residual form and is mostly present as $\mathrm{Cd}$ minerals, or is fixed crystal lattices [25-28].

\section{Modeling of saturation indexes for $\mathrm{Cd}$ minerals}

The Visual MINTEQ (version 2.23) chemical equilibrium speciation program was used to calculate saturation indexes for $\mathrm{Cd}$ minerals. Soil $\mathrm{pH}$ and ionic strength were fixed at the measured value, and in equilibrium with atmospheric $\mathrm{CO}_{2}$ were assumed to be $0.003 \mathrm{~atm}$. Calculations were performed with the input parameters for modeling $\mathrm{pH}$, ion strength, cations $\left(\mathrm{Ca}^{2+}, \mathrm{Cd}^{2+}, \mathrm{Fe}^{2+}\right.$, $\mathrm{Fe}^{3+}, \mathrm{K}^{+}, \mathrm{Mg}^{2+}, \mathrm{Na}^{+}, \mathrm{Ni}^{2+}, \mathrm{NH}_{4}^{+}, \mathrm{Pb}^{2+} \mathrm{Si}^{4+}$, and $\mathrm{Zn}^{2+}$ ), anions $\left(\mathrm{Cl}^{-}, \mathrm{CO}_{3}{ }^{2-}, \mathrm{NO}_{3}{ }^{-}, \mathrm{PO}_{4}{ }^{3-}\right.$, and $\left.\mathrm{SO}_{4}{ }^{2-}\right)$, and $\mathrm{DOC}$ at $25^{\circ} \mathrm{C}$. Soil $\mathrm{pH}$ was measured using a $\mathrm{pH}$ meter. Cations $\left(\mathrm{Ca}^{2+}, \mathrm{Cd}^{2+}, \mathrm{Fe}^{2+}, \mathrm{Fe}^{3+}, \mathrm{K}^{+}, \mathrm{Mg}^{2+}, \mathrm{Na}^{+}, \mathrm{Ni}^{2+}, \mathrm{Pb}^{2+} \mathrm{Si}^{4+}\right.$, and $\mathrm{Zn}^{2+}$ ) were quantified using an inductively coupled plasma mass spectrometer (ICP-MS; Thermo Scientific iCAP Q. Bremen, Germany). Ammonium concentrations were measured using a colorimetric method [29]. $\mathrm{Cl}^{-}$, $\mathrm{NO}_{3}{ }^{-}, \mathrm{PO}_{4}{ }^{3-}$, and $\mathrm{SO}_{4}{ }^{2-}$ contents were quantified using an ion chromatograph (IC; Dionex Corporation Model ICS-2000 IC, USA). Concentrations of bicarbonate $\left(\mathrm{HCO}_{3}{ }^{-}\right)$were measured using a potentiometric titration method [30].

\section{Production of carbonate species from CA decomposition by soil microbes}

In vitro tests were designed to determine the production of carbonate species $\left(\mathrm{H}_{2} \mathrm{CO}_{3}, \mathrm{HCO}_{3}{ }^{-}\right.$, and $\left.\mathrm{CO}_{3}{ }^{2-}\right)$ from the decomposition of $\mathrm{MB}$ including $\mathrm{CA}$ by soil microbes. Briefly, 500-ml aliquots of distilled water were added to $50 \mathrm{~g}$ samples of $\mathrm{Cd}$ free soil and the soil was incubated for $48 \mathrm{~h}$. Soil slurry was then filtered through $0.22 \mu \mathrm{m}$ cellulose acetate membranes. The filtered solutions were then inoculated into $200 \mathrm{ml}$ of BR medium containing $1.0 \mathrm{~g}^{-1}$; ammonium sulfate, $0.1 \mathrm{~g} \mathrm{l}^{-1}$ dipotassium hydrogen phosphate, $3.0 \mathrm{~g} \mathrm{l}^{-1}$ potassium dihydrogen phosphate, and $0.2 \mathrm{~g} \mathrm{l}^{-1}$ magnesium sulfate heptahydrate in a 500-ml Erlenmeyer flask. CA and MB were added to $\mathrm{BR}$ medium at 0 and $10 \mathrm{~g} \mathrm{l}^{-1}$. BR mediums were then incubated at $36^{\circ} \mathrm{C}$ for $120 \mathrm{~h}$ in a shaking incubator. After incubation, media were centrifuged, and the supernatants were discarded. To measure concentrations of all 
carbonate species $\left(\mathrm{H}_{2} \mathrm{CO}_{3}, \mathrm{HCO}_{3}{ }^{-}\right.$, and $\left.\mathrm{CO}_{3}{ }^{2-}\right)$, sample $\mathrm{pH}$ was adjusted at 8.34 using $0.005 \mathrm{M} \mathrm{NaOH}$ and $\mathrm{HCl}$, because all carbonate species are converted to $\mathrm{HCO}_{3}{ }^{-}$at $\mathrm{pH} 8.34$ [31]. Once sample $\mathrm{pH}$ values were stable, carbonates in suspensions were determined by potentiometric titrations [30].

\section{Statistical analysis}

Statistical analyzes were performed using Statistix version 9.0. Mean values of $\mathrm{Cd}$ fractions, soil $\mathrm{pH}$, and negative charges were compared using a pairwise differences method. Mean effects were separated using least significance differences when the appropriate $\mathrm{F}$ test was significant $(p<0.05)$.

\section{Results and discussion}

To identify the availability of heavy metals in contaminated soils, we performed a sequential extraction method for heavy metals as described in previous studies [20, 29, 32, 33]. Among the present fractions, F1 contained the most bioavailable Cd. Yet, F2 can be readily converted to $\mathrm{F} 1$ following changes in soil factors such as $\mathrm{pH}$, organic matter, mineralogy, and anions and cations on soil surfaces that are known to influence soil surface complexation $[34,35]$. Hence, F2 is thought to be the temporarily stable form of $\mathrm{Cd}$ fractions. In contrast, F5 is considered a stable form that is not readily changed into bioavailable forms under natural soil conditions. In this study, we assumed that the three Cd fractions F1, F2, and F5 are keys to evaluations of the effectiveness of $\mathrm{CA}$ and $\mathrm{MB}$ on the immobilization of $\mathrm{Cd}$.

\section{Effects of CA on Cd immobilization}

F1 concentrations significantly increased with the addition of CA compared with those of control experiments (Table 2). Hence, the bioavailability of Cd may be artificially increased by adding synthetic chelating agents such as CA. Similarly, other researcher report increases in exchangeable $\mathrm{Cd}$ fractions in soils treated with $\mathrm{CA}[11$, $15,18,36]$. Formation equilibrium constants for complex formation between $\mathrm{Cd}^{2+}$ and chelating agents are sufficiently high to extract bound $\mathrm{Cd}$ from soil matrixes. For example, a $\log K_{\mathrm{f}}$ of 4.54 was calculated for complexation of $\mathrm{Cd}^{2+}$ with $\mathrm{CA}$, where

$$
K_{\mathrm{f}}=\left[\mathrm{Cd}-\mathrm{CA}^{3-}\right] /\left[\mathrm{Cd}^{2+}\right]\left[\mathrm{CA}^{3-}\right]
$$

for the predominant complexed form of $\left[\mathrm{Cd}-\mathrm{CA}^{3-}\right]$ [37]. The addition of CA decreased the Cd contents of F2 by $2.64 \mathrm{mg} \mathrm{kg}^{-1}$ compared with the control and led to corresponding increases in Cd contents of $1.04 \mathrm{mg} \mathrm{kg}^{-1}$ and $1.49 \mathrm{mg} \mathrm{kg}^{-1}$ in $\mathrm{F} 1$ and $\mathrm{F} 5$ fractions, respectively (Table 2). These observations suggest that the $\mathrm{Cd}$ fraction was extracted and transformed to a bioavailable fraction and a residual fraction following application of CA. F5 associated with $\mathrm{Cd}$ precipitates and fixed $\mathrm{Cd}$ in crystal lattices markedly increased with CA. No previous reports show the effects of $\mathrm{CA}$ on increasing residual $\mathrm{Cd}$ fractions, because chelating agents such as CA are well known to increase $\mathrm{Cd}$ phytoextractability. Hence, in this study, we investigated the mechanisms by which F5 contents increased with CA addition. We hypothesized that (1) CA is decomposed by soil microorganisms, leading to the production of various carbonate species $\left(\mathrm{H}_{2} \mathrm{CO}_{3}\right.$, $\mathrm{HCO}_{3}{ }^{-}$, and $\mathrm{CO}_{3}{ }^{2-} ; \mathrm{H}_{x} \mathrm{CO}_{3}$ ), and (2) that increases in these carbonates promote $\mathrm{Cd}^{2+}$ precipitation as otavite $\left(\mathrm{CdCO}_{3}\right)$, leading to increased $\mathrm{F} 5$ concentrations.

To test the first hypothesis, $\mathrm{H}_{x} \mathrm{CO}_{3}$ concentrations from CA were measured in BR medium. CA significantly increased $\mathrm{H}_{x} \mathrm{CO}_{3}$ concentrations to about 11 fold that in controls (Fig. 1). This result was similar to observations by Bruce [38], who reported that $29-42 \%$ of carbonic acid was produced from the decomposition of CA by Bacillus sp.

To test the second hypothesis, we assumed that $\mathrm{Cd}^{2+}$ reacts with $\mathrm{H}_{x} \mathrm{CO}_{3}$ to form $\mathrm{CdCO}_{3}$, which was present at increased concentrations in fraction F5. Under these conditions, $\mathrm{H}_{x} \mathrm{CO}_{3}$ is dissociated in soil solutions according to the following reaction $[31,39]$ :

$$
\mathrm{H}_{2} \mathrm{CO}_{3} \leftrightarrow \mathrm{H}^{+}+\mathrm{HCO}_{3}^{-} \leftrightarrow \mathrm{H}^{+}+\mathrm{CO}_{3}^{2-}
$$

The first and second dissociation constants of carbonate species are 6.36 and 10.33, respectively. Hence, bicarbonate ion $\left(\mathrm{HCO}_{3}^{-}\right)$is the dominant carbonate species in our studied soil samples, which had $\mathrm{pH}=6.71$ (Table 1 ).

Table 2 Concentrations of Cd fractions in soils amended with and without citric acid (CA) after a 6-week incubation

\begin{tabular}{|c|c|c|c|c|c|c|c|c|}
\hline \multirow[t]{2}{*}{ Treatment } & \multicolumn{8}{|c|}{ Cadmium fraction $\left(\mathrm{mg} \mathrm{kg}^{-1}\right)$} \\
\hline & F1 & $\mathrm{F} 2$ & F3 & F4 & F5 & Sum & Total & $\begin{array}{l}\text { Recovery } \\
\text { rate }(\%)\end{array}$ \\
\hline Control & $4.62^{b}$ & $11.8^{\mathrm{a}}$ & $2.75^{\mathrm{a}}$ & $0.94^{\mathrm{a}}$ & $0.75^{b}$ & 20.9 & 20.4 & 102 \\
\hline$C A$ & $5.66^{\mathrm{a}}$ & $9.17^{b}$ & $2.72^{\mathrm{a}}$ & $0.98^{a}$ & $2.24^{\mathrm{a}}$ & 20.8 & 20.2 & 103 \\
\hline
\end{tabular}
at $25{ }^{\circ} \mathrm{C}$; differing superscript letters in columns indicate significant differences; $p=0.05$ 
Therefore, in equilibrated solutions, $\mathrm{CdCO}_{3}$ might be predominantly formed by the following reaction [40]:

$$
\mathrm{Cd}^{2+}+\mathrm{HCO}_{3}^{-} \rightarrow \mathrm{CdCO}_{3}(\mathrm{~s})+\mathrm{H}^{+}
$$

After 6-weeks incubation with $\mathrm{CA}$, soil $\mathrm{pH}$ increased slightly (Table 3), even though according to Eq. 2, soil pH should have decreased with CA. This discrepancy may be due to increased concentrations of carbonate ion $\left(\mathrm{CO}_{3}{ }^{2-}\right)$ from the decomposition of CA. $\mathrm{CO}_{3}{ }^{2-}$ increases soil $\mathrm{pH}$ according to the following reaction [31];

$$
\mathrm{CO}_{3}^{2-}+2 \mathrm{H}^{+} \rightarrow \mathrm{H}_{2} \mathrm{CO}_{3} \rightarrow \mathrm{CO}_{2}(\mathrm{~g})+\mathrm{H}_{2} \mathrm{O}
$$

We assumed that $\mathrm{Cd}^{2+}$ and $\mathrm{HCO}_{3}{ }^{-}$would be solubilized and supersaturated in solutions, allowing the formation of $\mathrm{CdCO}_{3}$. Theoretically, ions can precipitate from solutions when the ion activity product (IAP) is higher than the mineral solubility product $\left(\mathrm{K}_{\mathrm{sp}}\right)$. The saturation index $\left[\mathrm{SI}=\log \left(\mathrm{IAP} / \mathrm{K}_{\mathrm{sp}}\right)\right]$ is a practical indicator that can be used to determine whether the solution is in equilibrium with given inorganic mineral parameters, and when $\mathrm{SI}=0$, the soil solution is in equilibrium with the given $\mathrm{Cd}$ minerals. When $\mathrm{SI}>0$, the solution is supersaturated with respect to given $\mathrm{Cd}$ minerals, and when this value is $<0$ the soil solution is undersaturated relative

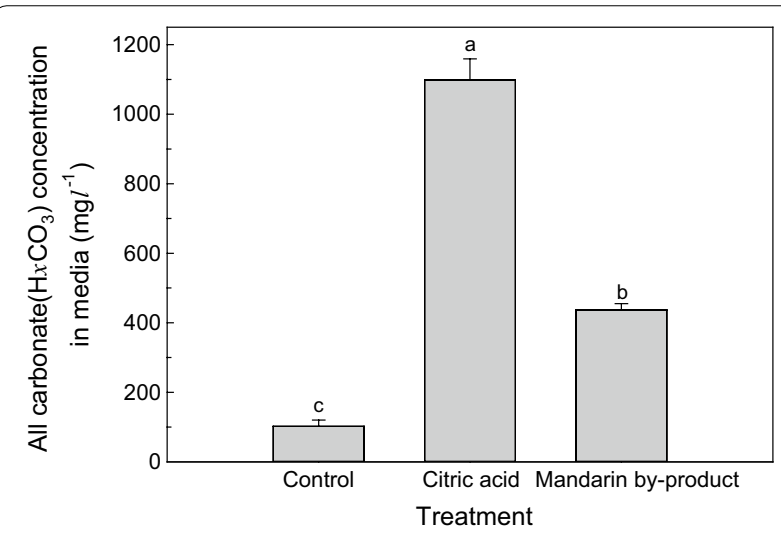

Fig. 1 Changes in concentrations of all carbonates in control, citric acid, and mandarin by-product amended soils after incubation at $25^{\circ} \mathrm{C}$ for 6 weeks; different letters on error bars indicate significant differences; $p=0.05$ to $\mathrm{Cd}$ minerals. Chemical immobilization treatments could change cadmium solubility and increase stability by precipitation of $\mathrm{Cd}$ minerals [41]. Especially, three $\mathrm{Cd}$ minerals $\left(\mathrm{CdCO}_{3}, \mathrm{Cd}_{3}\left(\mathrm{PO}_{4}\right)_{2}\right.$, and $\left.\mathrm{Cd}(\mathrm{OH})_{2}\right)$ may form but other $\mathrm{Cd}$ minerals $\left(\mathrm{CdCl}_{2}\right.$ and $\left.\mathrm{CdSO}_{4}\right)$ is too soluble to form in the natural soil environment [42]. To determine whether $\mathrm{Cd}^{2+}$ precipitated as $\mathrm{CdCO}_{3}, \mathrm{Cd}_{3}\left(\mathrm{PO}_{4}\right)_{2}$, and $\mathrm{Cd}(\mathrm{OH})_{2}$, SIs of these minerals were calculated using a chemical speciation program. The SI for all Cd minerals showed that soil suspensions of control and $\mathrm{CA}$ treatments were undersaturated relative to $\mathrm{Cd}_{3}\left(\mathrm{PO}_{4}\right)_{2}$ and $\mathrm{Cd}(\mathrm{OH})_{2}$ (Table 3). However, the SI for $\mathrm{CdCO}_{3}$ was higher than 0 in the presence of $\mathrm{CA}$, implying that $\mathrm{Cd}^{2+}$ and $\mathrm{HCO}_{3}{ }^{-}$activities in soil solutions with $\mathrm{CA}$ were high enough to form $\mathrm{CdCO}_{3}$.

Addition of $\mathrm{CA}$ enhanced concentrations of F5, potentially reflecting $\mathrm{Cd}$ precipitation induced by increases in $\mathrm{HCO}_{3}{ }^{-}$concentrations in soil solutions. These results indicate that CA could be used as a soil amendment to immobilize Cd. However, CA may not be an optimal amendment, because it increased residual and bioavailable $\mathrm{Cd}$ fractions (Table 2). Further studies are required to find soil amendments containing CA that increase only the stable $\mathrm{Cd}$ fraction in contaminated soils.

\section{Feasibility of MB as an amendment for immobilization of Cd}

Due to dilution, total Cd concentrations in soil decreased with increasing additions of MB (Table 4). Therefore, percentage distributions of $\mathrm{Cd}$ fractions in soil indicate the effects of $\mathrm{MB}$ on $\mathrm{Cd}$ bioavailability. Herein, recovery rates for $\mathrm{Cd}$ fractionation in incubated soils ranged from 97.4 to $103 \%$.

Portions comprising F1 significantly decreased with increasing additions of $\mathrm{MB}$, and corresponding increases were observed in F2, F3, and F5 fractions (Table 4). Specifically, $\mathrm{F} 1$ contents decreased by $8 \%$ following addition of MB at $40 \mathrm{~g} \mathrm{~kg}^{-1}$, and F2, F3, and F5 contents increased by $3.6 \%, 0.7 \%$, and $4.5 \%$, respectively. These data indicate that bioavailable $\mathrm{Cd}$ fractions were transformed into non-bioavailable $\mathrm{Cd}$ fractions following addition of $\mathrm{MB}$. Moreover, the present decreases in F1 are also likely due to $\mathrm{CA}$ decomposition from $\mathrm{MB}$ and from organic matter. As mentioned the above, a significant increases in

Table 3 Chemical properties of soil solutions amended with CA after a 6-week incubation at $25^{\circ} \mathrm{C}$; values with same

\begin{tabular}{|c|c|c|c|c|c|c|}
\hline \multirow[t]{2}{*}{ Treatment } & \multirow{2}{*}{$\begin{array}{l}\text { Soil pH } \\
\left(1: 5 \text { with } \mathrm{H}_{2} \mathrm{O}\right)\end{array}$} & \multicolumn{2}{|c|}{ Log activity $\left(\mathrm{mol} \mathrm{L}^{-1}\right)$} & \multicolumn{3}{|c|}{ Saturation index } \\
\hline & & $\mathrm{Cd}^{2+}$ & $\mathrm{HCO}_{3}^{-}$ & $\mathrm{CdCO}_{3}$ & $\mathrm{Cd}_{3}\left(\mathrm{PO}_{4}\right)_{2}$ & $\mathrm{Cd}(\mathrm{OH})_{2}$ \\
\hline Control & $6.73^{\mathrm{a}}$ & $-5.656^{b}$ & $-7.517^{b}$ & $-0.435^{b}$ & $-4.558^{\mathrm{a}}$ & $-4.781^{a}$ \\
\hline CA & $6.97^{\mathrm{a}}$ & $-5.228^{\mathrm{a}}$ & $-6.861^{\mathrm{a}}$ & $+0.572^{\mathrm{a}}$ & $-3.971^{\mathrm{a}}$ & $-4.347^{a}$ \\
\hline
\end{tabular}
letter within a column are significantly different; $p=0.05$ 
Table 4 Distributions of cadmium (Cd) fractions in soils amended with various quantities of mandarin by-product (MB) for 6 weeks at $25^{\circ} \mathrm{C}$; values with differing letters within a column are significantly different; $p=0.05$

\begin{tabular}{|c|c|c|c|c|c|c|c|c|}
\hline \multirow{2}{*}{$\begin{array}{l}\text { Addition rate } \\
\text { of } \mathrm{MB} \\
\left(\mathrm{g} \mathrm{kg}^{-1}\right)\end{array}$} & \multicolumn{5}{|c|}{ Cadmium fraction (\%) } & \multicolumn{3}{|c|}{ Cadmium concentration $\left(\mathrm{mg} \mathrm{kg}^{-1}\right)$} \\
\hline & $\mathrm{F} 1$ & F2 & F3 & F4 & F5 & Sum $^{1}$ & Total $^{2}$ & $\begin{array}{l}\text { Recovery } \\
\text { rate }(\%)^{3}\end{array}$ \\
\hline 0 & $22.1^{\mathrm{a}}$ & $56.6^{\mathrm{ab}}$ & $4.5^{\mathrm{a}}$ & $13.2^{\mathrm{a}}$ & $3.6^{c}$ & 20.9 & 20.4 & 102 \\
\hline 10 & $23.0^{\mathrm{a}}$ & $54.9^{\mathrm{b}}$ & $4.6^{\mathrm{a}}$ & $13.5^{\mathrm{a}}$ & $4.0^{c}$ & 19.7 & 20.0 & 98.5 \\
\hline 20 & $18.8^{\mathrm{b}}$ & $57.8^{\mathrm{ab}}$ & $4.8^{\mathrm{a}}$ & $12.4^{\mathrm{a}}$ & $6.2^{\mathrm{b}}$ & 18.3 & 18.8 & 97.4 \\
\hline 40 & $14.1^{\mathrm{C}}$ & $60.2^{\mathrm{a}}$ & $5.2^{\mathrm{a}}$ & $12.4^{\mathrm{a}}$ & $8.1^{\mathrm{a}}$ & 16.5 & 16.1 & 103 \\
\hline
\end{tabular}

1 Denotes sum of each $\mathrm{Cd}$ fraction concentration

2 Denotes total $\mathrm{Cd}$ concentration measured using the aqua regia digestion method

${ }^{3}$ Recovery rate $(\%)=($ Sum $/$ Total $) \times 100$

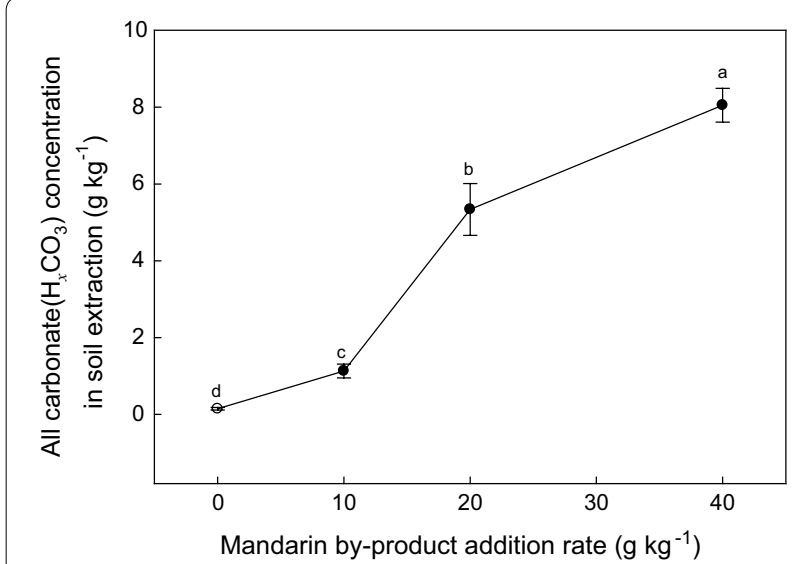

Fig. 2 Changes in concentrations of all carbonates in soils after amendment with varying levels of mandarin by-product at $25^{\circ} \mathrm{C}$ for 6 weeks; different letters on error bars indicate significant differences; $p=0.05$

F5 likely reflects $\mathrm{Cd}$ precipitation as $\mathrm{CdCO}_{3}$ following reactions with $\mathrm{H}_{x} \mathrm{CO}_{3}$ that is generated from the decomposition of CA in MB. As shown in Fig. $2, \mathrm{H}_{x} \mathrm{CO}_{3}$ concentrations dramatically increased with $\mathrm{MB}$ additions. Even though the portions of F2 and F3 did not differ significantly between treatments, the mean proportions increased with increasing MB additions (Table 4), potentially corresponding with consequent increased negative charges of soil samples. As shown in Table 5, organic matter concentrations and negative charges of soil samples were significantly increased with greater $\mathrm{MB}$ contents. Moreover, $\mathrm{Cd}$ adsorption and complexation with organic matter increased with the application of organic matter that possess many negatively charged functional groups, such as carboxyl $(\mathrm{COOH})$ and hydroxyl $(\mathrm{OH})$ groups, on its external surfaces $[29,43]$. The studied soil predominantly comprised kaolinite, which has a negative charge value of $4-14 \mathrm{cmol}_{\mathrm{c}} \mathrm{kg}^{-1}$. In contrast, humus reportedly has a negative charge of $130-300 \mathrm{cmol}_{\mathrm{c}} \mathrm{kg}^{-1}$ [44]. Hence, addition of the organic matter in MB dramatically increased the negative charge of soils, suggesting that portions of F2 and F3 increase with MB additions.

Soil $\mathrm{pH}$ dramatically decreased with additions of $\mathrm{MB}$ up to $20 \mathrm{~g} \mathrm{~kg}^{-1}$, and thereafter increased with MB additions up to $40 \mathrm{~g} \mathrm{~kg}^{-1}$ (Table 5). Various organic acids, such as ascorbic acid, lactic acid, malic acid, tartaric acid, and oxalic acid, can decrease soil $\mathrm{pH}$, but organic matter with many negatively charged functional groups, such as $\mathrm{COOH}$ and $\mathrm{OH}$, promotes increases in $\mathrm{pH}$. Therefore, soil $\mathrm{pH}$ likely decreased due to the presence of organic acids when $\mathrm{MB}$ was added to up to $20 \mathrm{~g} \mathrm{~kg}^{-1}$, and the

Table 5 Chemical properties of soil amended with various quantities of MB for 6 weeks at $25{ }^{\circ} \mathrm{C}$; values with differing letters within a column are significantly different; $\boldsymbol{p}=\mathbf{0 . 0 5}$

\begin{tabular}{|c|c|c|c|c|c|c|c|c|c|c|}
\hline \multirow[t]{2}{*}{$\begin{array}{l}\text { Addition rate } \\
\left(\mathrm{g} \mathrm{kg}^{-1}\right)\end{array}$} & \multirow[t]{2}{*}{$\begin{array}{l}\text { Soil pH } \\
\left(1: 5 \text { with } \mathrm{H}_{2} \mathrm{O}\right)\end{array}$} & \multirow[t]{2}{*}{$\begin{array}{l}\text { Total nitrogen } \\
\left(\mathrm{g} \mathrm{kg}^{-1}\right)\end{array}$} & \multirow[t]{2}{*}{$\begin{array}{l}\text { Organic matter } \\
\left(\mathrm{g} \mathrm{kg}^{-1}\right)\end{array}$} & \multirow{2}{*}{$\begin{array}{l}\text { Negative } \\
\text { charge } \\
\text { of soil } \\
\left(\mathrm{cmol}_{\mathrm{c}} \mathbf{k g}^{-1}\right)\end{array}$} & \multirow[t]{2}{*}{$\mathrm{C} / \mathrm{N}$ ratio } & \multirow{2}{*}{$\begin{array}{l}\text { Available } \\
\text { phosphorus } \\
\left(\mathrm{mg} \mathrm{kg}^{-1}\right)\end{array}$} & \multicolumn{4}{|c|}{$\begin{array}{l}\text { Exchangeable cation ( } \mathrm{cmol}_{\mathrm{c}} \\
\mathrm{kg}^{-1} \text { ) }\end{array}$} \\
\hline & & & & & & & $\overline{\mathrm{Ca}}$ & $\mathrm{K}$ & $\mathrm{Mg}$ & $\mathrm{Na}$ \\
\hline 0 & $6.82^{\mathrm{a}}$ & $1.05^{\mathrm{d}}$ & $11.5^{\mathrm{d}}$ & $6.85^{d}$ & $11.0^{\mathrm{a}}$ & $142^{\mathrm{a}}$ & $4.70^{d}$ & $0.44^{d}$ & $0.95^{d}$ & $0.37^{c}$ \\
\hline 10 & $4.44^{c}$ & $2.54^{c}$ & $25.2^{c}$ & $7.43^{c}$ & $9.92^{b}$ & $140^{\mathrm{a}}$ & $5.03^{c}$ & $0.81^{c}$ & $1.17^{c}$ & $0.42^{b c}$ \\
\hline 20 & $4.55^{c}$ & $5.18^{b}$ & $51.5^{b}$ & $8.70^{b}$ & $9.94^{b}$ & $137^{a}$ & $5.61^{b}$ & $1.29^{b}$ & $1.51^{\mathrm{b}}$ & $0.46^{\mathrm{ab}}$ \\
\hline 40 & $6.35^{b}$ & $9.50^{\mathrm{a}}$ & $97.9^{a}$ & $11.4^{\mathrm{a}}$ & $10.3^{b}$ & $144^{\mathrm{a}}$ & $6.14^{\mathrm{a}}$ & $2.10^{\mathrm{a}}$ & $2.09^{a}$ & $0.53^{\mathrm{a}}$ \\
\hline
\end{tabular}




Table 6 Correlation coefficients for relationships
between Cd fractions and chemical properties of soil
after amendment with varying quantities of MB
for 6 weeks at $25^{\circ} \mathrm{C} ; n=12$

\begin{tabular}{|c|c|c|c|c|c|}
\hline \multirow{2}{*}{$\begin{array}{l}\text { Soil } \\
\text { property }\end{array}$} & \multicolumn{5}{|l|}{ Cd fraction } \\
\hline & $\mathrm{F} 1$ & F2 & F3 & F4 & F5 \\
\hline Soil pH & -0.253 & +0.434 & +0.141 & +0.104 & +0.05 \\
\hline $\begin{array}{c}\text { Negative } \\
\text { charge }\end{array}$ & $-0.998^{* * *}$ & $+0.984^{* *}$ & +0.293 & -0.386 & $+0.783^{* *}$ \\
\hline $\mathrm{H}_{x} \mathrm{CO}_{3}$ & $-0.971^{* * *}$ & $+0.537^{*}$ & $+0.744^{* *}$ & $+0.623^{*}$ & $+0.993^{* * *}$ \\
\hline
\end{tabular}

$*^{* * *}$, and ${ }^{* * *}$ denote significance at $0.01,0.005$, and 0.001 levels of probability, respectively

increase in $\mathrm{pH}$ following addition of $40 \mathrm{~g} \mathrm{~kg}^{-1} \mathrm{MB}$ probably reflects of the presence of organic matter. Addition of large amount of organic matter that has many negatively charged functional groups on its external surface could increase negative charge of soil and cause deprotonation from soil solution. Subsequently, this might increase soil $\mathrm{pH}$. As shown in Table 5, negative charge of soil with $40 \mathrm{~g} \mathrm{~kg}^{-1}$ of MB dramatically increased from that with 0 , 10 , and $20 \mathrm{~g} \mathrm{~kg}^{-1}$ of MB. Other studies have also reported that the soil $\mathrm{pH}$ increased at high level of biosolid addition $[29,45]$.

Several studies show that the bioavailability of $\mathrm{Cd}$ can be limited by enhancing soil $\mathrm{pH}$ [23, 45-48]. However, $\mathrm{Cd}$ fractions were highly correlated with negative charges and concentrations of $\mathrm{H}_{x} \mathrm{CO}_{3}$ in our soil samples, rather than with soil pH (Table 6). F1 was negatively related with negative charges and $\mathrm{H}_{x} \mathrm{CO}_{3}$ concentrations in our soils. Yet F2 and F5 were positively correlated with negative charge and $\mathrm{H}_{\mathrm{x}} \mathrm{CO}_{3}$ concentrations, further suggesting that $\mathrm{MB}$ immobilizes $\mathrm{Cd}$ by promoting adsorption and precipitation of $\mathrm{Cd}$ as $\mathrm{CdCO}_{3}$ following reactions with the $\mathrm{H}_{x} \mathrm{CO}_{3}$ products of CA decomposition in MB. These reactions would be facilitated by increases in negative charges of soil surfaces that are likely induced by organic matter in MB. Unlike CA, MB increased non-bioavailable $\mathrm{Cd}$ fractions without increasing bioavailable $\mathrm{Cd}$ fractions, suggesting that as a soil amendment, $\mathrm{MB}$ can immobilize $\mathrm{Cd}$ in the soil without increasing its phytoavailability.

It will be difficult to apply $\mathrm{MB}$ as a soil amendment that immobilizes $\mathrm{Cd}$ in arable soils without concomitantly improving soil fertility and crop productivity. Although we provide no evidence of the effects of $M B$ on crop productivity, MB improved the chemical properties of soils, as shown in Table 5. Specifically, concentrations of nitrogen, organic matter, potassium, calcium, and magnesium and cation exchange capacities of our soil samples were significantly increased with increasing additions of $\mathrm{MB}$ after 6 -weeks incubation. However, soil $\mathrm{pH}$ decreased by 4.44 and 4.55 with additions of 10 and
$20 \mathrm{~g} \mathrm{~kg}^{-1} \mathrm{MB}$, respectively, and increased to 6.35 with $\mathrm{MB}$ at $40 \mathrm{~g} \mathrm{~kg}^{-1}$. Acidic soil $\mathrm{pH}$ conditions near $4.44-$ 4.55 have been shown to lower the availability of macro essential elements, such as nitrogen, phosphorous, potassium, calcium, and sulfur [49-52]. Subsequently, the low availability of these elements results in nutrient deficiencies of crops. Therefore, to prevent decreases in soil $\mathrm{pH}$, one may consider combined applications of $\mathrm{MB}$ and lime fertilizer to arable soils. Liming materials have mainly suggested that the most effective a soil amendment to increase soil $\mathrm{pH}[32,40,43]$. In addition, Liming materials improved not only availability of macro nutrient but also immobilization of cadmium which were attributed to the increase soil $\mathrm{pH}[32,50]$. Further studies of the combined effects of $\mathrm{MB}$ and lime fertilizer on Cd immobilization and soil $\mathrm{pH}$ are warranted.

\section{Acknowledgements \\ This research was supported by PNU-RENovation (2018-2019).}

\section{Authors' contributions}

$H H L$, DYH, HRH, YLP, CR, and SUK carried out soil sampling, soil analyses, and data organization. DCS, TKO, and $\mathrm{COH}$ participated in interpreting the obtained results and organizing the manuscript. All authors read and approved the final manuscript.

\section{Funding}

Not applicable.

Availability of data and materials

Not applicable.

\section{Competing interests}

The authors declare that they have no competing interests.

\section{Author details}

${ }^{1}$ Department of Life Science and Environmental Biochemistry, Pusan National University, Miryang 50463, Republic of Korea. ${ }^{2}$ Division of Applied Life Science (BK21 Program) \& Institute of Agriculture and Life Science, Gyeongsang National University, Jinju 52828, Republic of Korea. ${ }^{3}$ Department of Bio-Environmental Chemistry, Chungnam National University, Daejeon 34134, Republic of Korea. ${ }^{4}$ Life and Industry Convergence Research Institute, Pusan National University, Miryang 50463, Republic of Korea.

Received: 28 June 2019 Accepted: 10 August 2019

Published online: 28 August 2019

\section{References}

1. Nagajyoti PC, Lee KD, Sreekanth TVM (2010) Heavy metals, occurrence and toxicity for plants: a review. Environ Chem Lett 8:199-216. https://doi. org/10.1007/s10311-010-0297-8

2. U.S. Geological Survey (2019) Mineral commodity summaries. U.S. Geological Survey, Reston, pp 40-41

3. Gallego SM, Pena LB, Barcia RA, Azpilicueta CE, lannone MF, Rosales EP, Zawoznik MS, Groppa MD, Benavides MP (2012) Unravelling cadmium toxicity and tolerance in plants: insight into regulatory mechanisms. Environ Exp Bot 83:33-46. https://doi.org/10.1016/j.envexpbot.2012.04.006

4. Adriano DC (2001) Trace elements in terrestrial environments; biogeochemistry, bioavailability and risks of metals, 2nd edn. New York, Springer. https://doi.org/10.1007/978-0-387-21510-5

5. Noh YD, Park HJ, Kim KR, Kim WI, Jung KY, Kim SU, Owens VN, Moon JS, Yun SW, Kim SY, Hong CO (2017) Contrasting effect of phosphate on phytoavailability of arsenic and cadmium in soils supporting medicinal 
plants. Appl Biol Chem 60:119-128. https://doi.org/10.1007/s1376 5-017-0262-3

6. Ikeda M, Zhang ZW, Shimbo S, Watanabe T, Nakatsuka H, Moon CS, Matsuda-Inoguchi N, Higashikawa K (2000) Urban population exposure to lead and cadmium in east and south-east Asia. Sci Total Environ 249:373-384. https://doi.org/10.1016/s0048-9697(99)00527-6

7. Watanabe T, Zhang ZW, Moon CS, Shimbo S, Nakatsuka H, MatsudaInguchi N, Ikeda M (2000) Cadmium exposure of women in general populations in Japan during 1991-1997 compared with 1977-1981. Int Arch Occup Environ Health 73(1):26-34. https://doi.org/10.1007/pl000 07934

8. Agency for Toxic Substances and Disease Registry (2012) Toxicologic Profile for Selenium. GA US Department of Health and Human Services, Atlanta

9. Chiu KK, Ye ZH, Wong MH (2005) Enhanced uptake of As, Zn, and Cu by Vetiveria zizanoides and Zea mays using chelating agents. Chemosphere 60:1365-1375. https://doi.org/10.1016/j.chemosphere.2005.02.035

10. Erakhrumen AA (2007) Phytoremediation: an environmentally sound technology for pollution prevention, control and remediation in developing countries. Educ Res Rev 2(7):151-156

11. Greman H, Velikonja-Bolta S, Vodnik D, Kos B, Lestan D (2001) EDTA enhanced heavy metal phytoextraction: metal accumulation, leaching, and toxicity. Plant Soil 235:105-114

12. Jiang XJ, Luo YM, Zhang QG, Baker AJM, Christie P, Wong MH (2003) Soil $\mathrm{Cd}$ availability to indian mustard and environmental risk following EDTA addition to Cd-contaminated soil. Chemosphere 50:813-818. https://doi. org/10.1016/s0045-6535(02)00224-2

13. Lone MI, He Z, Stoffella PJ, Yang X (2008) Phytoremediation of heavy metal polluted soils and water: progresses and perspectives. J Zhejiang Univ Sci B 9:210-220. https://doi.org/10.1631/jzus.B0710633

14. McIntyre T (2003) Phytoremediation of heavy metals from soils. Adv Biochem Eng Biotechnol 78:97-123. https://doi.org/10.1007/3-540-45991 $-x 4$

15. Meers E, Ruttens A, Hopgood MJ, Samson D, Tack FMG (2005) Comparison of EDTA and EDDS as potential soil amendments for enhanced phytoextraction of heavy metals. Chemosphere 58:1011-1022. https:// doi.org/10.1016/j.chemosphere.2004.09.047

16. Rohma R (2017) Phytoremediation: an environmental friendly technique—a review. J Environ Anal Chem 4(2):195. https://doi. org/10.4172/2380-2391.1000195

17. Tangahu BV, Abdullah SRS, Basri H, Idris M, Anuar N, Mukhlisin M (2011) A review on heavy metals ( $\mathrm{As}, \mathrm{Pb}$, and $\mathrm{Hg}$ ) uptake by plants through phytoremediation. Int J Chem Eng. https://doi.org/10.1155/2011/939161

18. Copper EM, Sims JT, Cunniungham SD, Huang JW, Berti WR (1999) Chelate-assisted phytoextraction of lead from contaminated soils. J Environ Qual 28:179-198. https://doi.org/10.2134/jeq1999.004724250028000 $60004 x$

19. Kari FG, Hilger S, Canonica S (1995) Determination of the reaction quantum yield for the photochemical degradation of F2(III)-EDTA:implications for the environmental fate of EDTA in surface waters. Environ Sci Technol 29:1008-1017. https://doi.org/10.1021/es00004a022

20. Lee HH, Hong CO (2015) Contrast effect of citric acid and ethylenediaminetetraacetic acid on cadmium extractability in arable soil. Korean J Soil Sci Fertil 48:634-640 (in Korean)

21. Jeju special self-governing province citrus marketing \& shipping association (2017) analysis of distribution for mandarin in Jeju. http://www.citru s.or.kr/board/list. Accessed 10 Aug 2018 (in Korean)

22. Park JY (2017) Irresponsible disposal of mandarin in Jeju. Jejusidae. http:// jejusidae.com/news/articleView.html?idxno=3116. Accessed 28 Feb 2017 (in Korean)

23. Lee HH, Owens VN, Park S, Kim J, Hong CO (2018) Adsorption and precipitation of cadmium affected by chemical form and addition rate of phosphate ion soils having different levels of cadmium. Chemosphere 206:369-375. https://doi.org/10.1016/j.chemosphere.2018.04.176

24. Macrano-Martinez E, Mcbride MB (1989) Calcium and sulfate retention by two oxisols of the Brazilian cerrado. Soil Sci Soc Am J 53:63-69. https:// doi.org/10.2136/sssaj1989.03615995005300010012x

25. Marina C, Alleoni LRF, Kamogawa MY (2018) Cadmium sorption and extractability in tropical soils with variable charge. Environ Monit Assess 190:345. https://doi.org/10.1007/s10661-018-6666-7
26. Silveira ML, Alleoni LRF, O'Connor GA, Chang AC (2006) Heavy metal sequential extraction methods - a modification for tropical soils. Chemosphere 64:1929-1938. https://doi.org/10.1016/j.chemospher e.2006.01.018

27. Boruvka L, Drabek O (2004) Heavy metal distribution between fractions of humic substances in heavily polluted soils. Plant Soil Environ 50:339-345. https://doi.org/10.17221/4041-pse

28. Devi U, Bhattacharyya KG (2018) Mobility and bioavailability of Cd, Co, Cr, $\mathrm{Cu}, \mathrm{Mn}$ and $\mathrm{Zn}$ in surface runoff sediments in the urban catchment area of Guwahati, India. Appl Water Sci 8:18. https://doi.org/10.1007/s1320 1-018-0651-8

29. Kim SU, Owens VN, Kim SY, Hong CO (2017) Effect of different way of bottom ash and compost application on phytoextractability of cadmium in contaminated arable soil. Appl Biol Chem 60(4):353-362. https://doi. org/10.1007/s13765-017-0287-7

30. Lieu VT, Kalbus GE (1988) Potentiometric titration of acidic and basic compounds in household cleaners. J Chem Educ 65:184. https://doi. org/10.1021/ed065p184

31. Lindsay WL (1979) Chemical equilibria in soils Cadmium. The Blackburn Press, Caldwell, pp 316-327

32. Hong CO, Lee DK, Chung DY, Kim PJ (2007) Liming effects on cadmium stabilization in upland soil affected by gold mining activity. Arch Environ Contam Toxicol 52:496-502. https://doi.org/10.1007/s00244-006-0097-0

33. Sungur A, Soylak M, Ozcan H (2014) Investigation of heavy metal mobility and availability by the BCR sequential extraction procedure: relationship between soil properties and heavy metals availability. Chem Speciat Bioavailab 26:219-230. https://doi.org/10.3184/095422914x1414778115 8674

34. Li S, Wang M, Zhao Z, Ma C, Chen S (2018) Adsorption and desorption of $C d$ by soil amendment: mechanisms and environmental implications in field-soil remediation. Sustainability 10:2337. https://doi.org/10.3390/ su10072337

35. Najafi S, Jalali M (2015) Effects of organic acids on cadmium and copper sorption and desorption by two calcareous soil. Environ Monit Assess 187:1-10. https://doi.org/10.1007/s10661-015-4804-z

36. Svenson A, Kaj L, Bjorndal H (1989) Aqueous photolysis of the iron(III) complexes of NTA, EDTA and DTPA. Chemosphere 18:1805-1808. https:// doi.org/10.1016/0045-6535(89)90464-5

37. Ochoa-Loza FJ, Artioal JF, Maier RM (2001) Stability constants for the complexation of various metals with a rhamnolipid biosurfactant. J Environ Qual 30(2):479-485. https://doi.org/10.2134/jeq2001.302479x

38. Bruce WF (1934) The decomposition of citric acid by bacillus aertrycke. J Biol Chem 107:119-129

39. Sparks DL (2003) 1-Environmental soil chemistry: an overview. Environmental soil chemistry. Academic Press, San Diego. https://doi. org/10.1016/b978-012656446-4/50001-3

40. Lee HH, Kim SY, Owens VN, Park S, Kim J, Hong CO (2018) How does oyster shell immobilize cadmium? AECT 74:114-120. https://doi. org/10.1007/s00244-017-0453-2

41. Mench M, Vangronsveld J, Lepp NW, Edwards R (1998) Physicochemical aspects and efficiency of trace element immobilization by soils amendments. In: Vangronsveld J, Cunningham SD (eds) Metal-contaminated soils: in situ inactivation and phytorestoration. Springer, Berlin, pp 151-182

42. Hong CO, Chung DY, Lee DK, Kim PJ (2010) Comparison of phosphate materials for immobilizing cadmium in soil. AECT 58:268-274. https://doi. org/10.1007/s00244-009-9363-2

43. Bolan NS, Adriano DC, Mani PA, Duraisamy A (2003a) Immbilization and phytoavailability of cadmium in variable charge soils. II Effect of lime addition. Plant Soil 251:187-198. https://doi.org/10.1023/A:1023037706 905

44. Plaster E (2002) Soil science and management, 4th edn. Delmar Cengage Learning

45. Bolan NS, Adriano DC, Mani PA, Duraisamy A (2003b) Immbilization and phytoavailability of cadmium in variable charge soils. III. Effect of biosolid compost addition. Plant Soil 256:231-241. https://doi. org/10.1023/A:1026288021059

46. Hong CO, Lee DK, Kim PJ (2008) Feasibility of phosphate fertilizer to immobilize cadmium in a field. Chemosphere 70:2009-2015. https://doi. org/10.1007/s00244-009-9363-2 
47. Hong CO, Chung DY, Lee DK, Kim PJ (2010) Comparison of phosphate materials for immobilizing cadmium in soil. Arch Environ Contam Toxicol 58:268-274. https://doi.org/10.1007/s00128-014-1273-y

48. Hong CO, Owens VN, Kim YG, Lee SM, Park HC, Kim KK, Son HJ, Suh JM, Kim PJ (2014) Soil pH effect on phosphate induced cadmium precipitation in arable soil. Bull Environ Contam Toxicol 93:101-105. https://doi. org/10.1007/s00128-014-1273-y

49. Miller JO (2016) Soil pH affects nutrient availability .https://drum.lib.umd. edu/bitstream/handle/1903/18519/FS-1054\%20Soil\%20pH\%20and \%20Nutrient\%20Availbility.pdf. Accessed July 2016

50. Thomas $L$ (2010) Soil pH and the Availability of Plant Nutrients. https:// www.nutrientstewardship.com/implementation/soil-ph-and-the-avail ability-of-plant-nutrients/. Accessed Sept 2010
51. Havlin J, Beaton JD, Tisdale SL, Nelson WL (1999) Soil Fertility and Fertilizers: An Introduction to Nutrient Management, 6th edn. Prentice-Hall, Upper Saddle River

52. Jones JB (2012) Plant nutrition and soil fertility manual, 2nd edn. CRC Press, Boca Raton. https://doi.org/10.1201/b11577

\section{Publisher's Note}

Springer Nature remains neutral with regard to jurisdictional claims in published maps and institutional affiliations.

\section{Submit your manuscript to a SpringerOpen ${ }^{\circ}$ journal and benefit from:}

- Convenient online submission

- Rigorous peer review

- Open access: articles freely available online

- High visibility within the field

- Retaining the copyright to your article

Submit your next manuscript at $\boldsymbol{\nabla}$ springeropen.com 